\title{
Study on College English Pronunciation Teaching under the Flipped Classroom Teaching Model
}

\author{
Chen Ou \\ Chengdu Neusoft University, Chengdu, Sichuan Province, 611844
}

Keywords: flipped classroom; college English pronunciation teaching; constructivism

\begin{abstract}
At present, college English pronunciation teaching level needs to be improved, while flipped classroom teaching is an effective English phonetic teaching mode. This paper firstly analyzes the flipped classroom teaching mode, and then discusses the effective application of flipped classroom teaching mode in college English pronunciation teaching, aiming at exploring new and advanced teaching methods and promoting the improvement of college English pronunciation teaching level and quality.
\end{abstract}

\section{Introduction}

College English teaching is to cultivate students' ability of listening, speaking, reading and writing. Among them, oral English teaching and training is one of the most important contents, which requires oral English teaching to improve students' oral expression ability. However, in oral English teaching, phonetics teaching occupies an extremely important position. Only when students master good English phonetics can they express themselves in English more fluently and authentically.

\section{The Flipped Classroom Teaching Mode}

In the theory of teaching practice, cognitivism is gradually replaced by constructivism. In the constructionist view, the interaction between subject and object constructs the knowledge structure. The constructionist teaching concept emphasizes that in teaching, teachers do not impart knowledge theory directly to students, but give full recognition and respect to students' autonomy, and give students enough space to acquire knowledge theory through interaction and practice to construct their own knowledge system. Under the guidance of constructionist teaching concept, flipped classroom is an extremely effective teaching mode. In the flipped classroom mode, teachers integrate teaching knowledge and teaching resources before classroom teaching activities, and share them through network channels. Students learn and experience autonomously through online platforms. In the classroom, the teacher does not impart knowledge to the students, but the students conduct their own discussion, and the students show their learning results by themselves. In this process, the students' autonomy is mobilized to improve their enthusiasm, thus to better construct their own knowledge system.

With the continuous development and improvement of the modern education system, the university has gradually begun to carry out English teaching reform, and the traditional teaching concept has gradually been replaced by more advanced and cutting-edge teaching ideas and models. The status of students in teaching activities gradually changes, and education teaching emphasizes students' autonomy and initiative. The flipped classroom and other teaching modes are gradually adopted by education institutions. After a long period of trial and exploration, the teaching effect is gradually achieved. In addition, the reform of English teaching in Chinese universities has been carried out for a long time. Most college teachers have the skills and ability to make teaching courseware, share teaching resources and use multimedia equipment to process teaching resources, and have the professional competence and quality of teaching through teaching video, which also provides a good guarantee and support for the application of flipped classroom in college English phonetics teaching. 


\section{The Application of Flipped Classroom Mode in College English PronunciationTeaching}

In the flipped classroom mode, the college English phonetics teaching emphasizes the study of the pre-class period. The teacher prepares the teaching resources, integrates the various knowledge points of the phonetic teaching, and explains and demonstrates through the teaching means such as micro-course or moocs, so as to help the students obtain the corresponding knowledge in the extracurricular study, and cultivate the students' autonomy and initiative, thus effectively improving the students' learning quality and learning effect. College English phonetics teaching content mainly includes the knowledge of segmental phonemes, such as the interpretation of phonemes knowledge, English rhythm, supersound segment phoneme knowledge, etc. Through the network platform of these knowledge content, students are guided to acquire corresponding knowledge and training.

Teachers make teaching videos through the corresponding equipment, and and integrated audio, images, video, text and other forms of teaching resources through multimedia. Thus, knowledge is conveyed in the form of more interesting sharing, so it requires good control to the difficulty of the teaching resources. This can ensure that students can have a clear grasp of the corresponding knowledge points, and can face certain challenges due to the existence of corresponding knowledge difficulties, so as to arouse their enthusiasm for learning, and gain a better learning experience and learning effect ${ }^{[1]}$.

College English phonetic teaching is an important way of training students' language skills. Compared with other knowledge learning, the mastery of phonetic skills requires long-term, extensive phonetic imitation training, mechanical repetition of English phonetic learning materials, and cultivating their own language sense and voice skills through repeated repetition. Generally speaking, in college English phonetics teaching, students are unable to carry on because of boring repetitive training. Therefore, teachers need to prepare more abundant teaching materials for students in the process of preparing teaching resources, such as English songs, nursery rhymes, English tongue twisters, English poetry, dialogues of popular British TV series or American TV series, and so on. When choosing the corresponding English teaching materials, we need to combine the actual English phonetic teaching materials to carry out the content selection and arrangement of video, and cultivate students' different phonetic skills with different teaching materials. For example, the imitation learning of English nursery rhymes can cultivate students' phonetic rhythm, English songs can train students' English ability, and English dialogue can cultivate students' English language sense and intonation and so on. This is a more interesting way to guide students to conduct English phonetic learning and training.

In the age of the Internet, the spread and learning of knowledge is emerging as a feature of fragmentation and individuality. And the English voice teaching video is just enough to satisfy the student's fragmented English voice learning needs to improve the student's learning efficiency and learning quality. English phonetic teaching video, which is Shared on the Internet platform, can be downloaded or viewed online by students themselves. As long as the students have access to the Internet, they can control their learning process without any constrains of time or place, and they can control the progress of video according to their actual situation and learning needs. Consequently, the students' learning will be more suitable for themselves, more targeted and personalized.

College English phonetics teaching has a very clear teaching objective. By using the flipped classroom teaching mode to carry out college English phonetic teaching, students can be encouraged to study the progress and content of learning by using the application of more advanced teaching mode and teaching equipment. The students arrange the study content and the study time independently, according to the actual need of themselves to have the pertinence to carry on the repeated practice in a certain aspect. For example, many college students come from the south, and there are problems in the pronunciation of [n] and [1]. In this case, students need to choose their learning methods and resources according to their actual needs, and improve their own pronunciation through repeated practice and experiment ${ }^{[2]}$.

The application of flipped classroom teaching mode can realize the internalization of knowledge and skills through interactive learning between teachers and students and students in class, so as to 
better realize the improvement of pronunciation skills. College English phonetic teaching often needs to face a large number of students. When the course time is short and the class size is large, the students will have little time to communicate English phonetics after teaching English phonetic knowledge points. The application of flipped classroom teaching mode can effectively remedy this problem, provide students with enough time and space for classroom communication, internalize the knowledge learned before class, and further improve students' English pronunciation skills.

In the classroom practice of flipped classroom teaching mode, students and students, students and teachers need to have effective communication and interaction in the classroom teaching to exercise students' pronunciation ability. Teachers can adopt the way of collective discussion and group show for training. In addition, there is no fixed teaching mode for classroom teaching and training, so there is a very rich possibility. For example, teachers can organize students to play group games and create more interesting competitive situations for students through game competition. For another example, teachers demonstrate the relevant knowledge points of phonetic teaching to students, and improve students' interest through interesting deduction, so as to better conduct classroom interaction and communication, and help students to complete the absorption and internalization of knowledge.

In the teaching mode of flipped classroom, apart from pre-class preparation and in-class communication, it is also important to consolidate after class. In traditional English phonetic teaching, teachers and students have little chance to carry out more speech communication training, which leads to the separation of phonetics learning and English communication. There is no use of English phonetics for students to learn, and that would have an effect on the learning motivation and interest of the students. Under the application of flipped classroom teaching mode, students can gain more communication space and communication time in the classroom teaching stage. Besides, students can also consolidate and communicate with online students after class, so as to create more opportunities and space for students to improve their English pronunciation training and promotion ${ }^{[3]}$. For example, the teacher organizes online English corner or English radio drama competition, etc. Students can communicate through online channels and participate in English performances through English recording and other forms, so as to further improve students' interest in English communication and expression.

\section{Conclusion}

In college English phonetics teaching, the application of flipped classroom teaching mode includes the whole process of pre-class learning, in-class training and after-class communication. Teachers can use micro-course teaching and other modes. Teachers can share teaching resources with students, guide students to learn by themselves, and then arrange students to practice and communicate in class teaching, and help students to better consolidate and internalize English phonetic knowledge through online communication after-school.

\section{Acknowledgment}

Foundation Item: General project of Humanities and Social Sciences, Sichuan Provincial Education Department (2018): The Influence of Sichuan Dialect on English Phonetic Learning and Phonetic Teaching Strategies--An Empirical Study on the Negative Transfer of English Phonetics (Item no. 18SB0028)

\section{References}

[1] Niu Huihui, Han Nana. "An Empirical Study on the Impact of Flipped Classroom on the Phonetic Level of English Majors” [J]. Journal of Anyang Institute of Technology, 2016, 16(05):106-108+123.

[2] Wang Lili. "Feasibility Analysis of the Application of the Combination Model of Micro-course and Flipped Classroom in College English Courses” [J]. Times Education, 2016(13): 6-7. 
[3] Li Jing. "Study on Flipped Classroom Teaching Mode of College English Phonetics Teaching” [J]. Journal of Changchun Institute of Engineering (social science edition), 2016, 17(01): 149-152. 